\title{
Factors Associated with Timing and Choice of Complementary Feed Among Mothers Attending Immunization Clinics in Jos, Nigeria
}

\author{
Banwat, M.E ${ }^{1 *}$, Birdling, N. ${ }^{1}$, Mamza, $\mathrm{J}^{1}$, Bello, K.K ${ }^{1}$, Orya, E ${ }^{1}$, Bassi, A.P ${ }^{2}$ \\ ${ }^{1}$ Department of Community Medicine, Jos University Teaching Hospital, Jos, Nigeria \\ ${ }^{2}$ Department of Community Health, Bingham University, Abuja, Nigeria
}

\begin{abstract}
In Nigeria, Childhood nutrition and feeding are controlled and influenced by a lot of socio-cultural factors. The timing of initiation of Complementary feeds is a critical determinant of the nutritional status of children under five years of age. This study, therefore, set out to ascertain the Factors associated with the timing of initiation of complementary feeding among Children Aged 4-24 months of age, attending Routine Immunization Clinics in Jos North LGA of Plateau State, Nigeria. This was a descriptive, cross-sectional, facility-based study, using both quantitative and qualitative methods to assess the factors associated with the timing of initiation of complementary feeding among 210 mothers of children aged 4-12months. The FGD showed that mothers relied on past experience and finances to determine the timing of initiation of complementary feed. Although no Socio-demographic variable was found to be statistically associated with the timing of commencement of complementary feeding; more women commenced after 6months of age with tertiary education (68.3\%), if the child was female (70.4\%) and if the mother was younger age group (76.5\%). A larger proportion of the mothers initiated complementary feeding at the time they did, either because they felt the child was not satisfied with taking only breast-milk (37.1\%) or because they felt it was the best time to start (36.2\%). The most potent influence for the timing of complementary feed commencement was their past experience with other children.
\end{abstract}

Keywords: Commencement, Complementary, Feeding, Mothers, Timing.

\section{Introduction}

In Nigeria, Childhood nutrition and feeding are controlled and influenced by a lot of sociocultural factors. Mothers, as well as other family members like Fathers, Mothers-in-law and neighbours play a vital role in the choice of type of complementary feed as well as the timing of initiation of complementary feeds. The Level of compliance of mothers to these cultural systems of "control" is in turn, affected the mother's socio-demographics like her educational level, economic status, age, and cultural/religious beliefs [1].

The timing of initiation of Complementary feeds is a critical determinant of the nutritional status of children under five years of age. In a study done in China, $62.4 \%$ of mothers introduced formula feeds before the child was six months of age, while $21.2 \%$ did so when the child was between 6-12months of age. In the same study, it was found that $76 \%$ of mothers introduced complementary feeds at ages 4-6 months. Maternal age, educational status, employment, and infant's sex were associated with the early introduction of complementary feeds [2].

In Pakistan, researchers found that nearly $48 \%$ of mothers initiated complementary feeding between 6-9 months of age; More than $25 \%$ of the studied mothers started other foods aside breastmilk before the fourth $\left(4^{\text {th }}\right)$ month of the infant, and one in ten mothers did not initiate 
complementary feed until after the first year of life [3].

Findings from a Ghanaian study revealed that $55 \%$ of studied mothers introduced other foods aside breastmilk before the third month of life, while $37.9 \%$ did so before the fifth month of life. This practice was statistically associated with maternal age, advice from family, friends, and pressure from their daily work. [4]. Similarly, findings from a Ugandan study found that $50 \%$ of mothers initiated Complementary feeding before 6 months of age and over 30\% before the $4^{\text {th }}$ month of life [5].

A study in the Delta State of Nigeria showed that $67 \%$ of mothers initiated complementary feeding before the fourth $\left(4^{\text {th }}\right)$ month of life while $13 \%$ did so before the sixth $\left(6^{\text {th }}\right)$ month; leaving, only $10 \%$ fulfilling the WHO Criterion for the timing introduction of complementary feeds.[6]. Other researchers found that introduction of complementary feeds was done as early as 1-2 months of age (17.8\%) or in the third month of life (14.2\%) [7].

A study of the timing of initiations of complementary feeds will enable the planning of advocacy to employers of labor to provide crèches for mothers to enable exclusive breastfeeding to continue for 6 months before initiation of complementary feeds. This will then help in improving the nutritional statuses of the children and reduce the risk of malnutrition and its attendant effect on the children on both shortand long-term basis. This study, therefore, set out to ascertain the Factors associated with the timing of initiation of complementary feeding among Children Aged 4-24 months of age, attending Routine Immunization Clinics in Jos North LGA of Plateau State, Nigeria.

\section{Materials and Methods:}

\section{Description of the Site}

Nigeria is one of the most populous countries in Africa, with $70 \%$ of its population dwelling in rural areas and $42.5 \%$ of its population living below the poverty line. Female literacy is lower than the national average of $62.02 \%$, and immunization coverage averages $85 \%$.

Plateau State is one of the thirty-six states of Nigeria and is situated in the North Central region of the country between latitudes $80^{\circ} 24^{\prime}$ and $100^{\circ} 20^{\prime}$ north and longitudes $80^{\circ} 32^{\prime}$ and $100^{\circ} 38^{\prime}$ east. It occupies 30,913 square kilometres and shares boundaries with Kaduna State to the northwest, Nassarawa State to the southwest, Bauchi State to the northeast, and Taraba State to the southeast. The State capital is Jos, and the majority of the inhabitants are farmers (mainly in the rural areas) and civil servants, miners, and traders (mainly in the urban areas). Christianity and Islam are the major religions of the people. Plateau State is made up of seventeen LGAs grouped into three senatorial zones and had a population of $4,376,193$ in 2018 projected from the 2006 population census. (8) There are 946 health care facilities (HCFs) in Plateau State consisting of 736 publicly owned and 148 registered privately-owned primary HCFs, 21 public and 38 privates secondary HCFs, and 3 tertiary HCFs -2 public and 1 private. (9). Jos North is one of the 17 local government areas in Plateau State. It has an area of 291 sq. kilometres with a population of 429300 people based on the 2006 census. The indigenous languages are Berom and Afizere.

\section{Description of Statistical Methods Used}

\section{Minimum Sample Size Determination}

For qualitative data collection, it is expected that with a sample of two (2) FGDs, each with 810 participants, the information gotten from them will be sufficient to reach saturation point; sufficient enough to answer the objective of the FGD which is to get mothers' perspective on reasons for choice of timing and type of complementary feed used on index children aged 4-24 months of age, in Jos, Plateau State, NorthCentral Nigeria.

For Quantitative Data: The required sample size (n) was calculated using the formula for population estimate: 


\section{$\mathbf{n}=\mathbf{Z}^{2} \mathbf{p q} / \mathbf{d}^{2}$}

Where:

$\mathrm{z}=1.96$ at $95 \%$ confidence interval.

$\mathrm{p}=$ Prevalence of Wasting in Nigerian Children 4-24 months of age ${ }^{14}=10.6 \%$

$\mathrm{q}=1-\mathrm{p}=1-10.6=89.4 \%$

$\mathrm{d}=$ degree of precision which is $0.05=5 \%$

$\mathrm{n}=$ minimum required sample size

$\mathrm{n}=(1.96)^{2} \times 10.6 \times 89.4 /(5)^{2}$

$\mathrm{n}=3.8416 \times 10.6 \times 89.4 / 25$

$\mathrm{n}=146$

For non-response, inappropriate responses and incomplete responses, $10 \%$ was added to the sample size;

$10 / 100 \times 146=14.6=15$

Therefore, sample size is $=\mathrm{n}+10 \%$ of $\mathrm{n}=$ $146+15=161$

The minimum sample size was, therefore, 161 children.

However, 210 children were recruited for the study between March and June 2020.

\section{Sampling Method}

The subjects for the Focussed Group Discussion were sampled along with the help of the staff of the immunization clinics used for the FGDs. The Convenience sampling method was used to sample the 8-10 mothers used to gather the data for the FGD.

A multi-stage sampling technique was used to sample study subjects for the quantitative part of the report:

Stage one: (Selection of Health Facility) JUTH was selected from the list of the 4 tertiary health facilities in Jos North LGA, by Simple Random Sampling, by a table of random numbers.

The Plateau State Epidemiological Unit Clinic was also selected from the three stategovernment-owned immunization clinics in Jos North, by Simple Random Sampling, by a table of random numbers.

Stage two: (Selection of Clinic) There are three clinics that care for infants in JUTH; The Paediatric Outpatient clinic, The General Outpatient Clinic, and the Family Health Clinic
(FHC); The Family Health clinic was selected using Simple Random Sampling by the table of random numbers.

Only one clinic operates in the Epidemiological Unit, the routine immunization clinic, so it was selected.

Stage three: (Selection of Mothers/Infants) Both the FHC JUTH and the Epidemiological Unit Clinics run daily and offers routine immunization services to an average of 85 under-five children daily; however, with the COVID-19 control measure of "lockdown" by the State Government, the clientele dropped to about 10-20 children daily in both clinics.

Mothers of children aged $4-24$ months, who had already started complementary feeding, were recruited into the study consecutively as they registered into the clinic daily until the sample size was attained.

\section{Data Collection materials}

Quantitative data was collected using a semistructured interviewer administered questionnaire, adapted from the Multiple Indicator Cluster Survey questionnaire [9]. The questionnaire had three sections:

Section I: Socio-demographic characteristics of mothers and children.

Section II: Knowledge of Infant and Young Child Feeding Practices of Mothers.

Section III: Factors associated with the choice of and timing of initiation of complementary feed.

Qualitative data was collected from mothers by conducting two Focused Group Discussions with two groups of mothers on their perceptions of complimentary feeding and socio-cultural hindrances to proper complimentary feeding.

The FGD guide was made up of five (5) main open-ended questions formulated by the researcher, based on the objectives of the research.

\section{Data Analysis}

The Quantitative Data collected was analyzed using the Epi info version 3.5.4 computer 
software and is presented as tables and Charts. Significant relationships and associations were determined using the Chi-square $\left(\chi^{2}\right)$ test. A P value of $\leq 0.05$ was taken as statistically significant.

Qualitative data were transcribed and analyzed using thematic analysis manually. It is presented in prose form to triangulate with quantitative data.

\section{Results}

\section{Qualitative Results: Focus Group Discussions}

Two Focus Group Discussions (FGDs) on complementary feeding were conducted at two different immunization clinics in Jos North LGA. Each FGD had 8-10 mothers of children under five years of age in attendance and lasted for an averagely 1 hour. The recorded discussion sessions were transcribed verbatim into the English language. Themes and Sub-themes were coded for analysis and is presented in Tables 1 and 2 with quotations in some instances.

\section{Quantitative Results}

Non-Response Rate: Of the 231 respondents approached, only 210 consented to participate in the research, giving a non-response rate of $9.1 \%$.

A larger proportion of the mothers initiated complementary feeding at the time they did, either because they felt the child was not satisfied with taking only breast-milk $(37.1 \%)$ or because they felt it was the best time to start (36.2\%). The most potent influence for the timing of complementary feed commencement was their past experience with other children (Table 3).

No Socio-demographic variable was found to be statistically associated with the timing of commencement of complementary feeding. However, more women commenced after 6months of age with tertiary education (68.3\%), if the child was female (70.4\%) and if the mother was younger age group (76.5\%) (Table 3 ).

\section{Discussion}

There was no statistically significant association between the socio-demographics of the children/mothers with the choice of type of complementary feed used by the mothers. However, most mothers use home-made complementary feeds, irrespective of educational level, family setting, monthly income, and age group. Other researchers found out the mothers' beliefs that complementary foods would assist the infants' weight gain, sleeping patterns, and enjoyment at meal-times were identified as reasons for the choice of timing and type of complementary feed in Queensland. [10]. Other researchers in Kenya found out that home-made complementary feeds are commonly used because of their affordability; however, if care is not taken, they may not have the required complement of nutrients to encourage growth and development of the child, increasing the risk of undernutrition [11].

A larger proportion of the mothers initiated complementary feeding at the time they did, either because they felt the child was not satisfied with taking only breast-milk or because they felt it was the best time to start. No Sociodemographic variable was found to be statistically associated with the timing commencement of complementary feeding. However, more women commenced after 6 months of age with tertiary education (68.3\%), if the child was female (70.4\%) and if the mother was younger age group $(76.5 \%)$. A similar study in Ethiopia found out that factors associated with the timing of initiation of complementary feeds included being a government employee, having an educated husband, birth preparedness, growth monitoring, ability to know the exact time to introduce complementary feeding and paternal support. [12]. Another study in South-South Nigeria found out that few of the mothers started complementary foods at the age of 6 months, 
while the majority had begun complementary feeding before 6 months (73.5\%), and the rest delayed more than 6 months. [13]. Complementary feed needs to be started at 6 months to ensure that the child gets the required nutrients that breast-milk cannot supply by that age. Any introduction before or after this time period can predispose the child to malnutrition, either over-nutrition or under-nutrition.

The majority of the studied children in this research were on home-made complementary feeds at the time of the study. The major reason for the choice of type of complementary feed was the mothers' perception that the feed made their child healthy. This has positive public health implications as it would ensure that the child gets introduced to the family diet early in life, reduces cost for the family as well as makes the feed readily available for the child. On the other hand, for the period of time that the study was done, most of the country was on some form of Lock-down as a control measure for the COVID-19 pandemic, so sourcing for complementary feeds using cereals in the house was the only option for most mothers. This might mean that the food ran the risk of not being adequate in diversity because of poor financial and geographical access to nutritious proteinrich foods like milk; dietary diversity tends to assess the level of food group variety in the diet of the child. In this study, most of the children had a good dietary diversity. This would explain why their nutritional status, using almost every parameter of assessment, was majorly good. Other researchers found out the at the minimum, Dietary Diversity was not reached in $74 \%$ of children who were studied in Tanzania in 2016. [14]. This disparity could, however be explained by the fact that they studied children up to 6 years of age while this research only had children up to two years of age. A Kenyan study, however, found a dietary diversity similar to that of this study [15].

The Maternal factors statistically associated with having good dietary diversity in the complementary feed of the child included: Maternal education, Tribe, income, Complementary feeding, Knowledge, and practices of the mothers. Other researchers in Ethiopia found out that the Meal frequency was positively associated with dietary diversity. Women's involvement in household decisionmaking improves children's dietary diversity and ensures maternal health service utilization can contribute to better dietary diversity of children aged 6-23 months [16].

\section{Conclusion}

Therefore, it was concluded that past experience was the most prominent factor associated with the initiation and timing of complementary feeding among the studied mothers. Health workers need to therefore target first time mothers in giving nutrition education to ensure they comply to recommended IYCF practices.

\section{Tables}

Table 1: Responses of Respondents in FGD 1

\begin{tabular}{|l|l|l|l|}
\hline Themes & Sub-themes & Statements (N) & N \% \\
\hline $\begin{array}{l}\text { Determinants of } \\
\text { choice of food }\end{array}$ & $\begin{array}{l}\text { To keep the baby } \\
\text { healthy and grow } \\
\text { well }\end{array}$ & $\begin{array}{l}\text { Speaker 4: I choose the kind of food I } \\
\text { give my child because I want my child to } \\
\text { be healthy and to grow well. (4) }\end{array}$ & $5(15.7)$ \\
\cline { 2 - 3 } & $\begin{array}{l}\text { Speaker 8: To build up the body of the } \\
\text { baby very well so that it should look } \\
\text { healthy. (1) }\end{array}$ & 3 (9.3) \\
\cline { 2 - 3 } & Baby's preference & $\begin{array}{l}\text { Speaker 7: The choice of the baby also } \\
\text { matters, like my baby when he was just } \\
\text { starting to eat, he doesn't like }\end{array}$ & \\
\hline
\end{tabular}




\begin{tabular}{|c|c|c|c|}
\hline & & $\begin{array}{l}\text { Tombrown, I prepared it myself, but he } \\
\text { still preferred akamu because it is soft. } \\
\text { (1) }\end{array}$ & \\
\hline & & $\begin{array}{l}\text { Speaker 7: I bought cerelac, he refused it } \\
\text { just the pap. It's just the choice of the } \\
\text { baby. (1) }\end{array}$ & \\
\hline & \multirow[t]{2}{*}{ Low income } & Speaker 2: It is because of money sir. (1) & \multirow[t]{2}{*}{$4(12.6)$} \\
\hline & & $\begin{array}{l}\text { Speakers } 3 \text { and 6: For me, it is a lack of } \\
\text { money. (2) }\end{array}$ & \\
\hline & Nutritional content & $\begin{array}{l}\text { Speaker 4: For me, it is not the money } \\
\text { but the nutritional content because those } \\
\text { things are available here with us. (1) }\end{array}$ & $1(3.1)$ \\
\hline \multirow[t]{2}{*}{$\begin{array}{l}\text { Determinants of } \\
\text { when to commence } \\
\text { complementary } \\
\text { feeding }\end{array}$} & $\begin{array}{l}\text { Nurses' } \\
\text { recommendation } \\
\text { during antenatal } \\
\text { care clinic visit }\end{array}$ & $\begin{array}{l}\text { Speaker 3: I made that decision because } \\
\text { that's what I was told at antenatal that } \\
\text { after the period of } 6 \text { months, exclusive } \\
\text { breast-feeding is over, and after } 6 \\
\text { months, my baby can eat other foods. } \\
\text { Because the } 6 \text { months was over, I } \\
\text { introduced baby food. (1) }\end{array}$ & $5(15.7)$ \\
\hline & Baby cues & $\begin{array}{l}\text { Speaker 5: I started giving my baby food } \\
\text { at } 6 \text { months, and the reason is because as } \\
\text { soon as the baby sees food, she is eager } \\
\text { to eat, so she decided to start giving her. } \\
\text { (1) }\end{array}$ & $1(3.1)$ \\
\hline \multirow{4}{*}{$\begin{array}{l}\text { Reasons for choice } \\
\text { of complementary } \\
\text { feeds }\end{array}$} & \multirow[t]{2}{*}{ Nutritional value } & $\begin{array}{l}\text { Speaker 8: Because of nutritional value } \\
\text { and baby's preference. (1) }\end{array}$ & \multirow[t]{2}{*}{$2(6.3)$} \\
\hline & & $\begin{array}{l}\text { Speaker 4: I also mix guinea corn and } \\
\text { millet to make pap with wit; I felt it will } \\
\text { be more nutritious. I mixed them because } \\
\text { I felt it's not the same nutrients that are } \\
\text { in both of them so that they will have } \\
\text { more nutrients. (1) }\end{array}$ & \\
\hline & Affordability & $\begin{array}{l}\text { Speaker 5: I give pap and adult food } \\
\text { because that is what is available for me. I } \\
\text { give my child anything that is available } \\
\text { for me. (1) }\end{array}$ & $1(3.1)$ \\
\hline & Family influence & $\begin{array}{l}\text { Speaker 2: Its Dawa for me because my } \\
\text { mother told me to use Dawa (1) }\end{array}$ & $1(3.1)$ \\
\hline 5 & 15 & & $32(100)$ \\
\hline
\end{tabular}


Table 2. Responses of Respondents in FGD 2

\begin{tabular}{|c|c|c|c|}
\hline Themes & Sub-themes & Statements (N) & $\mathbf{N} \%$ \\
\hline \multirow[t]{6}{*}{$\begin{array}{l}\text { Determinants of } \\
\text { choice of food }\end{array}$} & \multirow[t]{2}{*}{$\begin{array}{l}\text { To keep the baby } \\
\text { healthy and grow } \\
\text { well }\end{array}$} & $\begin{array}{l}\text { Speaker 4: I am giving my child pap } \\
\text { because I want him to grow well and } \\
\text { help him develop strong muscles. It will } \\
\text { also give him the energy to play and be } \\
\text { intelligent. (4) }\end{array}$ & \multirow[t]{2}{*}{$5(15.7)$} \\
\hline & & $\begin{array}{l}\text { Speaker 7: I give him pap because it is } \\
\text { soft and smooth and easier to swallow } \\
\text { than canned foods. It is also cheaper. (1) }\end{array}$ & \\
\hline & Baby's preference & $\begin{array}{l}\text { Speaker 7: The baby swallows it easier } \\
\text { and does not spit it out or choke on it } \\
\text { because it is soft. (1) }\end{array}$ & $3(9.3)$ \\
\hline & \multirow[t]{2}{*}{ Low income } & $\begin{array}{l}\text { Speaker 9: It is cheaper to prepare it } \\
\text { myself than to buy canned foods. (1) }\end{array}$ & \multirow[t]{2}{*}{$4(12.6)$} \\
\hline & & $\begin{array}{l}\text { Speakers } 6 \text { and } 8: \text { With the lock-down, } \\
\text { prices of things have gone up, but I can } \\
\text { still afford the grains for his/her food } \\
\text { easily. (2) }\end{array}$ & \\
\hline & Nutritional content & $\begin{array}{l}\text { Speaker } 2 \text { : I add fish, eggs and milk in } \\
\text { the pap to make it nourishing to the body } \\
\text { of the child and he likes it's taste better } \\
\text { too. (1) }\end{array}$ & $1(3.1)$ \\
\hline \multirow[t]{3}{*}{$\begin{array}{l}\text { Determinants of } \\
\text { when to commence } \\
\text { complementary } \\
\text { feeding }\end{array}$} & \multirow[t]{2}{*}{$\begin{array}{l}\text { Nurses' } \\
\text { recommendation } \\
\text { during antenatal } \\
\text { care clinic visit }\end{array}$} & $\begin{array}{l}\text { Speaker } 5 \text { : I was told that by } 6 \text { months of } \\
\text { age, the breastmilk cannot give her all } \\
\text { the nutrients she needs, so I should start } \\
\text { other foods. (1) }\end{array}$ & \multirow[t]{2}{*}{$5(15.7)$} \\
\hline & & $\begin{array}{l}\text { Speaker 4: Antenatal and at } \\
\text { immunization clinic too, I was told to } \\
\text { start pap and other foods (4) }\end{array}$ & \\
\hline & Baby cues & $\begin{array}{l}\text { Speaker 1: She (baby) started following } \\
\text { my hand with her eye when I am eating } \\
\text { and seemed to like the taste when I put it } \\
\text { in her mouth, so I introduced it then. (1) }\end{array}$ & $1(3.1)$ \\
\hline \multirow[t]{3}{*}{$\begin{array}{l}\text { Reasons for choice } \\
\text { of complementary } \\
\text { feeds }\end{array}$} & Nutritional value & $\begin{array}{l}\text { Speaker } 7 \text { : A variety of grains mixed } \\
\text { together gives the child more nutrients to } \\
\text { grow (1) }\end{array}$ & $2(6.3)$ \\
\hline & Affordability & $\begin{array}{l}\text { Speaker 3: I feed my child with what I } \\
\text { can afford; I have other children to feed } \\
\text { too (1) }\end{array}$ & $1(3.1)$ \\
\hline & Family influence & $\begin{array}{l}\text { Speaker 7: My Mother and mother-in- } \\
\text { law suggested I use this cereal because } \\
\text { children can digest it, so I use it too (1) }\end{array}$ & $1(3.1)$ \\
\hline 5 & 15 & & $32(100)$ \\
\hline
\end{tabular}


Table 3. Frequency Table of Variables associated with Timing of Initiation of Complementary Feed

\begin{tabular}{|l|l|l|}
\hline Variable & Frequency & Percentage \\
\hline What Determines Timing of Initiation? & 13 & 6.2 \\
\hline I Need to Go Back to Work & 78 & 37.1 \\
\hline I Felt Child Was Not Satisfied with Breast Milk Alone & 76 & 36.2 \\
\hline It's Appropriate Age to Start & 43 & 20.5 \\
\hline I was Told to & \multicolumn{2}{|l|}{} \\
\hline Who Influences Your Nutritional Choices/Practice for the Child (multiple responses) \\
\hline Past experience & 102 & \\
\hline Sibling & 17 & \\
\hline Mother & 49 & \\
\hline Mother In-law & 18 & \\
\hline Neighbor & 11 & \\
\hline Others (HCW, Auntie, husband, Friend) & 47 & \\
\hline
\end{tabular}

Table 4. Socio-demographic Associations with Age at Commencement of Complementary Feed

\begin{tabular}{|c|c|c|c|c|c|c|}
\hline \multirow[t]{3}{*}{$\mathbf{S} / \mathbf{N}$} & \multirow[t]{3}{*}{ Variable } & \multicolumn{2}{|c|}{ Age at Commencement of Complementary Feed } & \multirow{3}{*}{$\begin{array}{l}\text { Total } \\
\text { F (\%) }\end{array}$} & \multirow[t]{3}{*}{$\chi^{2}$} & \multirow[t]{3}{*}{ P-value } \\
\hline & & \multirow{2}{*}{\begin{tabular}{|l|} 
Inappropriate \\
F (\%) \\
\end{tabular}} & \multirow{2}{*}{\begin{tabular}{|l|} 
Appropriate \\
F $(\%)$ \\
\end{tabular}} & & & \\
\hline & & & & & & \\
\hline \multirow[t]{5}{*}{1} & \multicolumn{6}{|c|}{ Educational Level } \\
\hline & None & $2(100.0)$ & $0(0.0)$ & $2(100.0)$ & $4.838^{*}$ & 0.223 \\
\hline & Primary & $4(36.4)$ & $7(63.4)$ & $11(100.0)$ & & \\
\hline & Secondary & $26(36.6)$ & $45(63.4)$ & $71(100.0)$ & & \\
\hline & Tertiary & $40(31.7)$ & $86(68.3)$ & $126(100.0)$ & & \\
\hline \multirow[t]{3}{*}{2} & \multicolumn{6}{|l|}{ Tribe } \\
\hline & $\begin{array}{l}\text { Plateau } \\
\text { indigenous }\end{array}$ & $38(34.5)$ & $72(65.5)$ & $110(100.0)$ & 0.007 & 0.934 \\
\hline & Non-Indigenous & $34(34.0)$ & $66(66.0)$ & $100(100.0)$ & & \\
\hline \multirow[t]{3}{*}{3} & \multicolumn{6}{|l|}{ Religion } \\
\hline & Islam & 19(33.9) & $37(66.1)$ & $56(100.0)$ & 0.004 & 0.948 \\
\hline & Christianity & $53(34.4)$ & $101(65.6)$ & $154(100.0)$ & & \\
\hline \multirow[t]{4}{*}{4} & \multicolumn{6}{|l|}{ Family setting } \\
\hline & Nuclear & $2(100.0)$ & $0(0.0)$ & $2(100.0)$ & $4.838^{*}$ & 0.223 \\
\hline & Extended & $4(36.4)$ & $7(63.4)$ & $11(100.0)$ & & \\
\hline & & $26(36.6)$ & $45(63.4)$ & $71(100.0)$ & & \\
\hline \multirow[t]{3}{*}{5} & \multicolumn{6}{|c|}{ Monthly Income } \\
\hline & $<\$ 30,000$ & $57(33.9)$ & $111(66.1)$ & $168(100.0)$ & 0.048 & 0.827 \\
\hline & $\geq \mathbf{N} 30,000$ & $15(35.7)$ & $27(64.3)$ & $42(100.0)$ & & \\
\hline \multirow[t]{3}{*}{6} & \multicolumn{6}{|c|}{ Age Group of Children (Months) } \\
\hline & $4-11$ & $50(33.1)$ & 101(66.9) & $151(100.0)$ & 0.328 & 0.567 \\
\hline & $12-24$ & $22(37.3)$ & $37(62.70$ & $59(100.0)$ & & \\
\hline \multirow[t]{3}{*}{7} & \multicolumn{6}{|l|}{ Child's Sex } \\
\hline & Male & $56(35.9)$ & $100(64.1)$ & $156(100.0)$ & 0.699 & 0.403 \\
\hline & Female & $16(29.6)$ & $38(70.4)$ & $54(100.0)$ & & \\
\hline
\end{tabular}




\begin{tabular}{|l|l|l|l|l|l|l|}
\hline 8 & \multicolumn{2}{|l|}{ Mother's Age Group (Years) } \\
\cline { 2 - 7 } & $15-21$ & $4(23.5)$ & $13(76.5)$ & $17(100.0)$ & $3.981^{*}$ & 0.291 \\
\cline { 2 - 7 } & $22-28$ & $25(38.5)$ & $40(61.5)$ & $65(100.0)$ & & \\
\cline { 2 - 7 } & $29-35$ & $30(31.9)$ & $64(68.1)$ & $94(100.0)$ & & \\
\cline { 2 - 7 } & $13(41.9)$ & $18(58.1)$ & $31(100.0)$ & & \\
\cline { 2 - 7 } & $43-49$ & $0(0,0)$ & $3(100.0)$ & $3(100.0)$ & & \\
\hline
\end{tabular}

\section{Conflict of interest}

The Researchers have no conflict of interest to declare.

\section{Acknowledgement}

The researchers would like to acknowledge and appreciate the time of the respondents

\section{References}

[1] World Health Organization (WHO), 2001, The Global Consultations in Complementary Feeding. (Cited November 18, 2019); Available from: http://www.who.into/nutrition/complementary_feedi $\mathrm{ng} / \mathrm{en} /$.

[2] Luibia L, Sijin L, Ali M and Ushijima H (2005). Feeding practice of infants and their correlates in urban areas of Beijing, China. Pediatric International.; 45(4) 400-406.

[3] Syed M.A. (2001) Poverty and child mortality in Pakistan. Pakistan Institute of Development Economics, Islamabad. Mumap Technical paper series No 6, available at; http://pide.org.ph/Mimap/report06. (Cited November 18, 2020).

[4] Solomon S.B (2010). Socio-cultural factors influencing infant feeding practices of mothers attending a clinic in Cape-Coast. Department of sociology and Anthropology, University of CapeCoast, Ghana. Cited $19^{\text {th }}$ December 2019.

[5] Mikori A and Orikushaba P. (2012) Nutritional status, Complementary feeding practice and feasible strategies to promote nutrition in wollen, Uganda. African Journal on Nutrition; 25(4): 173-179.

[6] Ogunba B.O. (2006), Maternal Behavior, Feeding Practices, and Under-five nutrition: Implications for child development and care, Journal of Applied Scientific Resources, 2(12), 1132-1136. (mothers of the studied children) to the data collection in this study. We would also like to appreciate the health workers in both immunization clinics for their time and cooperation during data collection.

[7] Angio K.M., Ameh D.A., Ibrahim S, and Danbauchi S.S, (2009), Infant Feeding Practice and Nutritional Status of Children in North-Western Nigeria. Asian Journal of Clinical Nutrition; (2), 1222.

[8] National Population Commission (2008), National Demographic and Health Survey, MD, USA NPC and ORC macro calverton p.163-174.

[9] National Bureau of Statistics (NBS) and United Nations Children's Fund (UNICEF). 2017 Multiple Indicator Cluster Survey 2016-17, Survey Findings Report. Abuja, Nigeria: NBS and UNICEF.

[10] Walsh, A., Kearney, L. \& Dennis, N. Factors influencing first-time mothers' introduction of complementary foods: a qualitative exploration. BMC Public Health 15, 939 (2015). https://doi.org/10.1186/s12889-015-2250-z (Cited November 18, 2020).

[11] Abeshu, M. A., Lelisa, A., \& Geleta, B. (2016). Complementary Feeding: Review of Recommendations, Feeding Practices, and Adequacy of Homemade Complementary Food Preparations in Developing Countries - Lessons from Ethiopia. Frontiers in nutrition, 3, 41. https://doi.org/10.3389/fnut.2016.00041.

[12] Reda, E. B., Teferra, A. S., \& Gebregziabher, M. G. (2019). Time to initiate complementary feeding and associated factors among mothers with children aged 6-24 months in Tahtay Maichew district, 
northern Ethiopia. BMC research notes, 12(1), 17. https://doi.org/10.1186/s13104-019-4061-2 (Cited November 18, 2019).

[13]Udoh, E. E., \& Amodu, O. K. (2016). Complementary feeding practices among mothers and nutritional status of infants in Akpabuyo Area, Cross River State Nigeria. SpringerPlus, 5(1), 2073. https://doi.org/10.1186/s40064-016-3751-7 (Cited November 19, 2020).

[14] Khamis, A.G., Mwanri, A.W., Ntwenya, J.E. et al. (2019) The influence of dietary diversity on the nutritional status of children between 6 and 23 months of age in Tanzania. BMC Pediatr 19, 518
(2019). https://doi.org/10.1186/s12887-019-1897-5. [15]Badake, D, Maina, I., Mboganie, M.A., Muchemi, G., Kihoro, E.M., Chelimo, E., and Mutea, K. (2014) Nutritional Status of Children Under Five Years and Associated factors In Mbeere South District, Kenya. African Crop Science Journal, Vol. 22, (S4):799 - 806 Issn 1021-9730/2014.

[16] Temesgen, H., Yeneabat, T. \& Teshome, M., (2018) Dietary diversity and associated factors among children aged 6-23 months in Sinan Woreda, Northwest Ethiopia: a cross-sectional study. BMC Nutr 4, 5. https://doi.org/10.1186/s40795-018-02142 (Cited November 18, 2020). 